\author{
Anna Mtynarczuk-Sokolowska \\ Wydzią Pedagogiki i Psychologi \\ UNIWERSYTET W BIAŁYMSTOKU \\ E-MAIL: ANNAMLYNARCZUK@TLEN.PL
}

\title{
BLIŻEJ ODMIENNOŚCI. TWÓRCZA AKTYWNOŚĆ W MIĘDZYKULTUROWEJ EDUKACJI NIEFORMALNEJ
}

\section{Wprowadzenie}

Od dawna podkreśla się, że edukacja powinna być kompatybilna z procesami społeczno-kulturowymi oraz ich następstwami. Akcentuje się, że działania edukacyjne powinny wykraczać poza bierny przekaz wiedzy i koncentrować się na twórczym działaniu, które służy kreatywnemu rozwijaniu osobowości i tym samym realizacji wielu priorytetów społecznych. W dobie migracji i dynamicznego różnicowania się współczesnych społeczeństw wzrasta zainteresowanie edukacją międzykulturową, której celem jest przygotowanie społeczeństwa do życia w warunkach różnorodności. Edukacja międzykulturowa, dzięki bogatej metodyce, stwarza przestrzeń do twórczej aktywności i umożliwia kreatywne uwrażliwianie na odmienność. Jest również czynnikiem twórczego odkrywania własnej, niepowtarzalnej tożsamości.

Celem artykułu jest prezentacja możliwości implementacji idei edukacji międzykulturowej do praktyki edukacyjnej poprzez wykorzystanie metod służących kreatywnemu uczeniu się. W tekście, wychodząc od prezentacji założeń edukacji międzykulturowej, przedstawię trzy instruktywne przykłady dobrych praktyk edukacyjnych zakładających poznawanie Obcych i Innych za pomocą twórczej aktywności (literackiej, plastycznej, fotograficznej). Scharakteryzowane przeze mnie inicjatywy wpisują się w kanon międzykulturowej edukacji nieformalnej, która ze względu na swoją specyfikę (w tym nieobligatoryjny charakter), ma szczególne znaczenie w procesie kształtowania kompetencji międzykulturowej. Każda z nich zakładała wykorzystanie kilku form aktywności twórczej. Zostały one zrealizowane 
we współpracy organizacji pozarządowych z podmiotami zajmującymi się kształceniem i resocjalizacją, z myślą o potrzebach i możliwościach poznawczych różnych grup społecznych.

\section{Założenia edukacji międzykulturowej}

Edukacja międzykulturowa stanowi próbę odpowiedzi na wyzwania wynikające ze zróżnicowania przestrzeni społecznej i edukacyjnej oraz konsekwencje funkcjonowania w warunkach różnicy: kulturowej, językowej czy ekonomicznej. Zakłada wzajemne poznawanie się ludzi i kultur oraz uwrażliwianie na odmienność. Prowadzi do wzajemnego przejmowania (godnych tego) wzorów życia, wzajemnego wzbogacania się kultur, kooperacji, przyjaźni i podejmowania wspólnych działań na rzecz wielokulturowych społeczeństw i/lub społeczności [Lewowicki 2011: 10-11]. Ten rodzaj edukacji jest płaszczyzną poznawania Obcych i Innych, doświadczania różnic międzyludzkich i międzykulturowych, wykraczania poza stereotypy i uprzedzenia oraz rozwijania własnej tożsamości.

„Istotą edukacji międzykulturowej jest [...] uchwycenie tego, co wspólne, chociaż inne, a nie unifikowanie wartości i kultur" [Kamińska 2005: 11]. „W edukacji międzykulturowej nie chodzi o zacieranie różnic, ale o świadomość ich istnienia" [Lewowicki 2000: 31]. Edukacja międzykulturowa nie koncentruje się tylko na najprostszej formie tolerancji, czyli takiej, która umożliwia poznanie Obcego i Innego i cierpliwe znoszenie go. Dąży ku otwieraniu się na inność, zrozumieniu odmienności, kształtowaniu pozytywnego stosunku do niej oraz pełnych postaw tolerancji i poszanowania każdej osoby, która przejawia jakikolwiek rodzaj inności [Różańska 2011: 127]. Umożliwia pokonywanie drogi od myślenia o innych w kategoriach zagrażających Obcych do myślenia o nich jako o interesujących Innych. Przede wszystkim ma uczyć mediacji i rozwiązywania konfliktów [Nikitorowicz 2009: 281]. Służy przezwyciężaniu wszelkich wykluczeń społecznych i edukacyjnych wywołanych odmiennością narodową, etniczną, kulturową, wyznaniową i zapobieganiu tym zjawiskom [Lewowicki 2011: 11]. Jest narzędziem inkluzji edukacyjnej i społecznej.

Edukacja międzykulturowa może przebiegać spontanicznie - w rodzinie lub społeczności lokalnej oraz w planowy sposób - w szkole czy środkach masowego przekazu (mając związek ze społeczną polityką państwa), [Maj 2005: 279]. Uzasadnione jest więc traktowanie edukacji międzykulturowej jako całożyciowego procesu, który obejmuje: edukację formalną (szkolną), 
nieformalną (nieszkolną, nieobligatoryjną) i pozaformalną/incydentalną (spontaniczną), które wzajemnie przenikają się i uzupełniają.

Szczególne znaczenie $\mathrm{w}$ procesie poznawania odmienności ma międzykulturowa edukacja nieformalna [zob. m.in. Rogers 2004]. Tego typu edukacja ma dobrowolny charakter. Treści i metody działań edukacyjnych są dostosowywane do potrzeb i możliwości danej grupy. Międzykulturowa edukacja nieformalna daje szereg możliwości osobom projektującym i prowadzącym ją, jak i jej uczestnikom. Wykracza poza bierny przekaz wiedzy, koncentrując się na aktywnym działaniu. Może być realizowana za pomocą różnych metod angażujących sferę intelektualną, emocjonalną oraz behawioralną.

Jedną z wielu ścieżek realizacji międzykulturowej edukacji nieformalnej jest kreatywne działanie za pomocą ekspresji werbalnej, plastycznej czy ruchowej. Twórcza aktywność stanowi naturalny proces rozwoju, autokreacji i komunikowania się ze światem [Nęcka 2001: 19-24]. Zgodnie z egalitarnymi koncepcjami twórczości każdy człowiek posiada twórczy potencjał, który możne wyzwalać i rozwijać [Nęcka 2001]. Praca twórcza stwarza więc warunki do pozbawionego wszelkich ograniczeń uczenia się poprzez wyrażanie siebie i przyglądanie się sobie (swoim poglądom, emocjom, postawom). Może więc odgrywać istotną rolę w procesie przygotowania ogółu społeczeństwa do kontaktów z Obcym i Innym. Dzięki wielu formom ekspresji, angażując wyobraźnię i intuicję, stwarza możliwość aktywnego odkrywania dziedzictwa kulturowego różnych grup etnicznych, narodowych czy religijnych. Odwołując się do emocji i osobistych przeżyć, daje szansę wykraczania poza negatywne stereotypy i uprzedzenia. Jest również czynnikiem samopoznania.

Edukacja międzykulturowa w Polsce zaczęła dynamicznie rozwijać się po transformacji ustrojowej, wraz z przyjęciem ładu demokratycznego, co wiązało się między innymi z uznaniem praw mniejszości oraz umożliwieniem swobodnej aktywności obywatelskiej. Obecnie w ramach kształcenia szkolnego oraz edukacji nieformalnej podejmowanych jest wiele inicjatyw, które mają na celu budowanie dialogowych relacji z Obcym i Innym.

Istotną rolę $\mathrm{w}$ zakresie realizacji edukacji międzykulturowej odgrywają sami obywatele, zrzeszeni w organizacjach pozarządowych. W wielu środowiskach fundacje i stowarzyszenia przodują, a nawet wypełniają lukę w realizacji edukacji międzykulturowej. Podejmowane przez nie inicjatywy kierowane są do różnych grup społecznych (wiekowych, zawodowych, narodowych). Dzięki współpracy organizacji pozarządowych ze szkołami, 
centrami kultury, placówkami, które zajmują się wychowaniem i opieką, powstaje wiele partnerskich inicjatyw. Działania realizowane przez organizacje pozarządowe przyjmują różne formy działalności edukacyjnej. Należą do nich: cykliczne projekty edukacyjne, szkolenia, workcampy, wymiany międzynarodowe. Inicjatywy polskich organizacji pozarządowych w wielu przypadkach cechują się innowacyjnością.

\section{Międzykulturowa edukacja nieformalna w praktyce}

\section{Konkurs „Różnorodność przestrzenią dialogu”}

Adresatami konkursu są dzieci w wieku przedszkolnym i wczesnoszkolnym, przynależące do grupy większościowej, mniejszości narodowych i etnicznych oraz dzieci cudzoziemskie. Inicjatywa ma zasięg wojewódzki. Jest organizowana cyklicznie przez Fundację Uniwersytetu w Białymstoku i Szkołę Podstawową nr 26 w Białymstoku. Jej celem jest kształtowanie wrażliwości na szeroko rozumianą odmienność. Działanie składa się z kilku następujących po sobie etapów. Należą do nich: aktywności wspierające przygotowanie prac konkursowych (warsztaty edukacyjne, pogadanki z nauczycielami, rodzicami, wycieczki edukacyjne), które umożliwiają zainicjowanie rozmów i podjęcie refleksji na temat różnorodności, przygotowywanie prac konkursowych oraz edukacyjna impreza podsumowująca wyniki konkursu.

W ramach inicjatywy dzieci uczęszczające do przedszkoli oraz szkół podstawowych tworzą prace literackie, plastyczne bądź wykonują fotografie dotyczące różnorodności. Co roku konkurs organizowany jest pod innym hasłem, na przykład: „Inny bliski i daleki”, „Zwyczaje i tradycje domu rodzinnego”, „Ulubione gry i zabawy”, które tematycznie ukierunkowuje pracę dzieci. Za pomocą różnych form ekspresji twórczej, literackiej, plastycznej oraz fotograficznej, dzieci angażują się w twórczy proces przygotowywania wierszy, opowiadań, rysunków czy zdjęć, ukazujących wybrane zagadnienia związane $\mathrm{z}$ różnorodnością. W ten sposób mają okazję zaprezentować to: jak widzą swoją przynależności kulturową (w tym tradycje, zwyczaje, dziedzictwo kulturowe regionu), kim jest dla nich Obcy i Inny i na jakie napotyka problemy, jaki jest ich stosunek do odmienności, jakie międzyludzkie i międzykulturowe podobieństwa dostrzegają.

Podsumowanie konkursu co roku ma miejsce w Szkole Podstawowej nr 26 podczas otwartej dla społeczności lokalnej imprezy edukacyjnej, która 
jest organizowana w okolicach Światowego Dnia Uchodźcy. Dzieje się tak, ze względu na fakt, iż Szkoła Podstawowa nr 26 przoduje w Białymstoku pod względem liczby uczniów cudzoziemskich (są to głównie Czeczeni). Jest to dobra okazja, by zaakcentować ich obecność.

Impreza ma uroczysty charakter. W jej toku są eksponowane prace uczestników konkursu. Poza wręczeniem nagród wyróżnionym, stałym jej elementem są części artystyczna oraz edukacyjna. W trakcie spotkania dzieci mają możliwość kontaktu z twórczością i doświadczenia odmienności, poprzez obserwację występów zespołów pieśni i tańca innych narodów. Niekiedy przygotowują przedstawiania o tematyce międzykulturowej, co pozwala im między innymi wejść w rolę Obcego i Innego i tym samym poczuć, jak to jest się różnić w relacjach społecznych. Impreza podsumowująca, poprzez udział dzieci w grach o charakterze edukacyjnym, pozwala im również poszerzyć wiedzę na temat różnorodności otaczającego je świata. Prace uczestników konkursu stanowią inspirację do przygotowywania zadań dydaktycznych, które mają służyć uwrażliwianiu na odmienność podczas imprezy. Motywują również do dyskusji na temat ich treści.

Co roku w trakcie spotkania podsumowującego konkurs, specjalne miejsce poświęcone jest kulturze czeczeńskiej. Zarówno uczestnicy inicjatywy, jak i przybyli goście mają możliwość poznać elementy tej odległej dla wielu osób kultury. Przybliżanie kultury czeczeńskiej ma miejsce za sprawą projekcji filmów, wystąpień dzieci czeczeńskich (prezentacje, pokazy), quizów edukacyjnych. Tradycyjnie, co roku można obejrzeć występ zespołu tańca dziecięcego „Lowzr” oraz spróbować przygotowanych przez rodziców tradycyjnych czeczeńskich dań. Organizację imprezy wspierają wolontariusze z Fundacji Uniwersytetu w Białymstoku i Fundacji „Dialog”.

Jedna $\mathrm{z}$ inicjatorek konkursu w następujący sposób opisała zasadność jego organizowania:

Istotne jest żeby od najwcześniejszych lat przybliżać dzieciom różnorodność otaczającego je świata, zaciekawiać jej bogactwem oraz wyjaśniać, że może być ona źródłem wielu pozytywnych doświadczeń. Szkolna rzeczywistość pokazuje, że odmienność jest często powodem odrzucenia i niechęci. Udział w konkursie umożliwia dzieciom poznawanie różnorodności w naturalny sposób - poprzez aktywność twórczą - i czerpanie przyjemności z pracy twórczej. Jest to ważny element edukacji międzykulturowej najmłodszych, naturalna droga poznawania świata ${ }^{1}$.

1 Źródło: notatki własne. 
Edukacja międzykulturowa, realizowana za pomocą metod i form pracy umożliwiających twórczą aktywność, jest adekwatną do możliwości percepcyjnych oraz intelektualnych najmłodszych odbiorców działań edukacyjnych, drogą poznawania odmienności. Udział w konkursie stanowi dla dzieci duże wzywanie. Jest swoistą przygodą, która przybliża świat Obcego i Innego oraz umożliwia samopoznanie. Dzięki twórczej aktywności dzieci mają możliwość spontanicznego wypowiedzenia się na temat ważnych kwestii związanych z heterogenicznością ludzkiej rzeczywistości. Udział w inicjatywie daje możliwość wyboru i cieszenia się różnymi formami artystycznego wyrazu. Stanowi bodziec do namysłu na temat odmienności, własnego dziedzictwa kulturowego oraz relacji z Obcym i Innym. W twórczy sposób rozwija wrażliwość na odmienność, która jest ważnym elementem partnerskiego funkcjonowania w środowisku zróżnicowanym kulturowo. Budzi zainteresowanie odmiennością, pozwala dostrzec to, co łączy ludzi różniących się od siebie. Partycypacja w działaniu, dzięki twórczej aktywności, w wielu przypadkach jest pierwszym, „bezpiecznym” (bo na płaszczyźnie ekspresji twórczej), krokiem ku realnemu spotkaniu z Obcym i Innym.

\section{„Uwiecznić Atlantydę” - warsztaty wielokulturowe i fotograficzne}

Projekt był adresowany do młodzieży gimnazjalnej z Wasilkowa i Krynek, z różnych środowisk wychowawczych (w tym dysfunkcyjnych). Został zrealizowany przez Fundację Uniwersytetu w Białymstoku, Gimnazjum w Wasilkowie oraz Gimnazjum w Krynkach. Celem działania było rozwijanie zainteresowań wielokulturowością Podlasia. W ramach inicjatywy zostały przeprowadzone cykliczne warsztaty: integrujące młodzież, fotograficzne w plenerze (umożliwiające naukę profesjonalnej obsługi aparatów fotograficznych), dotyczące wybranych elementów kultur Podlasia (białoruska, romska, tatarska, żydowska) oraz edukacyjna wycieczka śladami wielokulturowości regionu (Tykocin, Kruszyniany, Bohoniki, Krynki, Święta Woda).

W trakcie projektu młodzież miała możliwość doświadczenia wielokulturowości Podlasia poprzez szereg aktywności sprzyjających twórczej ekspresji: ruchowej, plastycznej oraz fotograficznej, której poświęcono najwięcej miejsca. Młodzież poznawała wybrane elementy kultur regionu między innymi poprzez: naukę tańca (tradycyjny taniec białoruski), wykonywanie prac plastycznych przy wykorzystaniu techniki frotażu (w celu odczyty- 
wania transkrypcji na nagrobkach białostockiego kirkutu), samodzielne fotografowanie (w plenerze). Praca $\mathrm{z}$ aparatem umożliwiała uwiecznianie „podlaskiej Atlantydy”, czyli - w rozumieniu inicjatorów projektu - cennego dziedzictwa, które jest narażone na utratę w czasach nieustannych przemian.

Uczestnicy działania, dzięki twórczemu zaangażowaniu, za pomocą aparatów fotograficznych, rejestrowali własny sposób postrzegania wielokulturowości Podlasia i tym samym przedstawiali to, co ich zdaniem stanowi jej rdzeń. Prace wykonane przez młodzież, w oryginalny sposób, ukazywały głównie artefakty religii i wyznań Podlasia: krzyże, macewy, mury synagog, meczety oraz elementy ich wyposażenia.

Projekt edukacyjny „Uwiecznić Atlantydę...” zakończył się otwartą imprezą edukacyjną skierowaną do społeczności lokalnej, która odbyła się $\mathrm{w}$ gimnazjum w Wasilkowie. Podczas spotkania osoby zainteresowane mogły zobaczyć efekty pracy młodzieży zaprezentowane $\mathrm{w}$ formie wystawy, wysłuchać wystąpień ekspertów podejmujących w swojej pracy problematykę wielokulturowości (naukowca, fotografa) oraz refleksji młodzieży związanych $\mathrm{z}$ udziałem $\mathrm{w}$ projekcie. Uczestnictwo w imprezie było bodźcem do rozmów na temat bogatej i różnorodnej spuścizny regionu oraz motywowało do pamiętania o wielokulturowej przeszłości i teraźniejszości.

Przeprowadzona przez realizatorów działania ewaluacja projektu wskazuje na to, iż uczenie się poprzez twórcze zaangażowanie, w odczuciu gimnazjalistów, jest inspirującym oraz adekwatnym do potrzeb młodych ludzi sposobem realizacji edukacji międzykulturowej. Potwierdza to między innymi następująca wypowiedź jednej z uczestniczek omawianej inicjatywy:

Miłą niespodzianką, która spotkała nas już na pierwszych zajęciach, było zaangażowanie profesjonalnego, wykształconego fotografa w pracę z całą grupą. Przekazał on nam nie tylko suchą teorię, ale również w terenie zarażał swoją pasją do fotografowania [...]. Alfabet hebrajski, detale synagogi, frotaż, historia meczetu i kultura Tatarów, zwyczaje pogrzebowe wyznawców islamu, tańce białoruskie - wszystko to i jeszcze więcej, naprawdę zainteresowało nas, podlaską młodzież bardzo zafascynowaną własnym regionem. Zajęcia w terenie są idealnym sposobem na poznawanie walorów północnego wschodu Polski [za: Młynarczuk, Sokołowski 2010: 65]. 
„Multikulturowe warsztaty edukacyjno-artystyczne dla kobiet osadzonych w Areszcie Śledczym Warszawa - Grochów"

Adresatkami projektu były kobiety odbywające karę pozbawienia wolności w Areszcie Śledczym Warszawa-Grochów. Większość z nich stanowiły recydywistki. Działanie zostało zainicjowane przez Fundację „Dom Kultury”. Celem projektu było wspieranie procesu readaptacji społecznej za pomocą edukacji międzykulturowej. Inicjatywę konstruowały następujące działania: warsztaty multikulturowe, multikulturowe warsztaty edukacyjno-artystyczne (w tym zajęcia taneczne, bębniarskie i plastyczne), warsztaty kulinarne różnych narodów oraz wystawa prac przygotowanych podczas projektu. Działanie zakładało również nagranie wideoklipu obrazującego zajęcia taneczne i bębniarskie. Inicjatorka projektu w następujący sposób opisała jego zadania:

Nasze warsztaty są atrakcyjną i inspirującą propozycją zagospodarowania wolnego czasu i ukierunkowania zainteresowań. Stanowią remedium na odizolowanie od społeczeństwa, tęsknotę za rodziną, bezczynność, nudę i samotność, a także brak perspektyw na życie po opuszczeniu zakładu. Są „artystycznym pomostem” - nawiązaniem kontaktu ze społecznością „na zewnątrz” i przez to ułatwieniem skazanym powrotu do społeczeństwa. Ułatwieniem i przygotowaniem tego powrotu ${ }^{2}$.

Na każdym etapie inicjatywy kobiety miały szansę działać w twórczy sposób, poznając wybrane elementy kultur krajów afrykańskich, kaukaskich oraz kultury romskiej, żydowskiej i kolumbijskiej. Odbywało się to za pomocą multimedialnego pokazu połączonego z prezentacją przedmiotów związanych z daną kulturą oraz poprzez bezpośrednie spotkania z Innymi (m.in. Czeczenką, Senegalczykiem).

Multikulturowe warsztaty edukacyjno-artystyczne umożliwiły naukę tańców charakterystycznych dla innych niż polska kultur (afrykańskiego, żydowskiego i tańca brzucha), grę na bębnach oraz samodzielne tworzenie artefaktów kultury (biżuteria). Nauka tańca i gry na bębnach pozwoliła kobietom, w metafizyczny sposób, doświadczyć dalekich kultur. Wykonywanie biżuterii $\mathrm{z}$ ornamentami charakterystycznymi dla kultur romskiej, kolumbijskiej i ormiańskiej, było swoistą lekcją tworzenia dóbr kultury materialnej. Warsztaty kulinarne, poprzez kreatywne przygotowywanie dań narodowych, stały się płaszczyzną doświadczania różnorodności tradycyj-

2 Źródło: notatki własne. 
nych specjałów. Sprzyjały poznawaniu odmiennych kultur poprzez zmysł smaku.

W ramach podsumowania odbyła się wystawa prac kobiet, które wykonały w trakcie projektu. Prace więźniarek zostały zaprezentowane społeczności lokalnej. Dzięki temu osoby zainteresowane mogły odkryć twórczy potencjał uczestniczek warsztatów i spojrzeć na nie przez pryzmat ich kreatywności. Warsztaty bębniarskie i taneczne zostały uwiecznione za pomocą wideoklipu.

Warsztaty odbywające się $\mathrm{w}$ ramach projektu umożliwiały rozwijanie wśród kobiet zainteresowań artystycznych oraz umiejętności konstruktywnego spędzania czasu wolnego. Prowadzone działania były czynnikiem rozwijania zainteresowań różnorodnością świata oraz dawały szansę kształtowania postaw otwartych wobec odmienności. Twórcza aktywność, koncentrująca się na poznawaniu Obcych i Innych, stanowiła zarówno istotny element samopoznania, jak też resocjalizacji i inkluzji społecznej osadzonych kobiet.

\section{Podsumowanie}

Twórcza aktywność umożliwia nabywanie doświadczeń stanowiących źródło wiedzy o świecie i sobie samym. Jest niezbędna w trakcie rozwoju osobistego, działań edukacyjnych i tym samym w realizacji ważnych zadań społecznych i edukacyjnych. W toku międzykulturowej edukacji nieformalnej, dla której bardzo ważne jest kreatywne uczenie się poprzez doświadczenie i działanie, twórcza aktywność może stanowić narzędzie realizacji innowacyjnych działań edukacyjnych, adresowanych do wielu różnych grup społecznych - inicjatyw, które uwzględniają zarówno problematykę różnic, jak i podobieństw międzyludzkich i międzykulturowych. Zaprezentowane $\mathrm{w}$ tekście działania umożliwiały poznawanie odmienności za pomocą różnych form ekspresji twórczej: literackiej, plastycznej, fotograficznej czy muzycznej, dzięki twórczemu zaangażowaniu zarówno sfery poznawczej, jak też emocjonalnej i behawioralnej.

Treści analizowanych inicjatyw dotyczyły wybranych elementów kultur istniejących w danej społeczności lokalnej, regionie oraz odległych krańcach świata i tym samym determinowały ich specyfikę. Zaprezentowane inicjatywy służyły realizacji ważnych celów społecznych, takich jak: kultywowanie pamięci społecznej, kształtowanie tożsamości regionalnej, integracja międzykulturowa, wspieranie procesu resocjalizacji. Wszystkie 
stanowiły płaszczyznę poznawania Innych i Obcych, kształtowania wrażliwości na odmienność oraz budowania pozytywnych relacji w zróżnicowanej przestrzeni ludzkiej. Zakładały uczenie się poprzez korzystanie z potencjału twórczego ludzi w różnym wieku i sytuacjach życiowych. Cechą znamienną poszczególnych inicjatyw i zarazem je różnicującą były miejsca ich realizacji: szkoła, przestrzeń wielokulturowego Podlasia oraz areszt śledczy.

\section{Bibliografia}

Kamińska K. (2005), W stronę wielokulturowości w edukacji przedszkolnej, Warszawa

Lewowicki T. (2000), W poszukiwaniu modelu edukacji międzykulturowej, (w:) Edukacja międzykulturowa w Polsce i na świecie, Katowice

Lewowicki T. (2011), Wprowadzenie, (w:) T. Lewowicki, A. Szczurek-Boruta, J. Suchodolska (red.), Pedagogika międzykulturowa wobec wykluczenia społecznego i edukacyjnego, Cieszyn-Warszawa-Toruń

Maj B. (2005), Podstawowe środowiska wychowawcze wobec idei edukacji międzykulturowej (w:) A. Szerląg (red.), Wielokulturowość - międzykulturowość obszarami edukacyjnych odniesień, Kraków

Młynarczuk A., Sokołowski M. (red.) (2010), Uwiecznić Atlantydę. Wielokulturowość Podlasia w edukacji nieformalnej, Białystok

Nęcka E. (2001), Psychologia twórczości, Gdańsk, Gdańskie Wydawnictwo Psychologiczne. Nikitorowicz J. (2009), Edukacja regionalna i międzykulturowa, Warszawa

Rogers A. (2004), Non-formal education: Flexible schooling or participatory education?, Hong Kong

Różańska A. (2011), Poznajemy Innego, pozbywamy się stereotypów i kształtujemy tolerancje, (w:) T. Lewowicki, J. Suchodolska (red.), Dzieci w procesie ksztaltowania postaw kulturowych, Katowice-Cieszyn-Warszawa-Kraków 
SUMMARY

\section{Closer to otherness. Creative activity in the non-formal intercultural education}

The main purpose of this paper is to show the role of creative activity in non-formal intercultural education. The author presents creative ways of implementing the idea of non-formal intercultural education within the educational process. On the basis of the non-formal intercultural education postulates, she analyses three examples of educational initiatives (directed to children, teenagers and adults), which included creative activity (literary, artistic, photographic, etc.).

Keywords:

creative activity, cultural diversity, intercultural competence, non-formal intercultural education, the Other/Stranger 